\title{
PENGARUH RESTRAIN TERHADAP PENURUNAN SKORE PANSS EC PADA PASIEN SKIZOFRENIA DENGAN PERILAKU KEKERASAN
}

\author{
Retno Yuli Hastuti*, Nurwulan Agustina, Widiyatmoko \\ Program Studi Sarjana Keperawatan Keperawatan, STIKES Muhammadiyah Klaten \\ *hastuti.puteri@gmail.com
}

\begin{abstract}
ABSTRAK
Kasus perilaku kekerasan di RSJD Dr. RM. Soedjarwadi Provinsi Jawa Tengah adalah sebanyak 158 orang yang di restrain sebanyak 72 orang dan nilai panss EC adalah gaduh gelisah. Penanganan yang dilakukan adalah dengan menenangkan pasien dan memberikan terapi restrant dengan tepat sesuai SOP selama 24 jam sehingga menurunkan perilaku kekerasan pada pasien skizofrenia yang dinilai dengan skor Panns EC. Tujuan penelitian ini untuk mengetahui Pengaruh Restrain terhadap Penurunan Skor Panss EC pada Pasien Skizofrenia dengan Perilaku Kekerasan di Ruang Edelweis Rumah Sakit Jiwa Daerah Dr. RM. Soedjarwadi Provinsi Jawa Tengah. Desain penelitian ini menggunakan Quasy Eksperimental dengan rancangan One Group Pre Test-Post Test Design, Populasi pada penelitian ini adalah semua pasien perilaku kekerasan di RSJD dr. RM. Soedjarwadi Provinsi Jawa Tengah sebanyak 158 orang. Teknik sampling yang digunakan concecutive sampling, analisa data paired t-test. Hasil. Karakteristik responden meliputi umur yaitu 26-45 tahun, jenis kelamin adalah laki-laki dan pekerjaan adalah tidak bekerja. Skor Panss EC pada pasien skizofrenia sebelum dilakukan restrain di yaitu gaduh gelisah dengan mean 21,90. Skor Panss EC pada pasien skizofrenia setelah dilakukan restrain yaitu gelisah dengan mean 19,50 Kesimpulan. Ada Pengaruh Restrain terhadap Penurunan Skor Panss EC pada Pasien Skizofrenia dengan Perilaku Kekerasan dengan nilai $p=0,000(\alpha<0,05)$
\end{abstract}

Kata kunci: restrain, skizofrenia, skor panss EC, perilaku kekerasan

\section{THE EFFECT OF RESTRAIN ON IMPAIRMENT OF EC PANSS SCORES IN SCHIZOPHRENIC PATIENTS WITH VIOLENT BEHAVIOR}

\begin{abstract}
Cases of violent behavior in RSJD Dr. RM. Soedjarwadi Central Java province as many as 158 people in restrained as many as 72 people and the value of EC panss is noisy anxiety. The handling is to calm the patient and provide restrant therapy, restrain implementation is done by tying the hands of the patient to sleep for 24 hours to reduce the in schizophrenic patients with violent behavior with eczema score. Aim. To know the effect of Restrain on Impairment of EC Panss Scores in Schizophrenic Patients with Violent Behavior in Edelweis Room Mental Hospital Area Dr. Soedjarwadi Central Java Province. Method. The design of this study using Quasy Experimental with the design of One Group Pre-Test Post Test Design, Population in this study are all patients violent behavior in RSJD dr. RM. Soedjarwadi Central Java Province as many as 158 people. Sampling technique used concecutive sampling, paired t-test data analysis. Results. Characteristics of respondents include age ie 26-45 years, gender is male and job is not working. Panss EC score in schizophrenic patients before restrained in Edelweis Room Mental Hospital Area Dr. Soedjarwadi Central Java Province is anxious with a mean of 21.90. Panss EC score in schizophrenic patients after restrained is anxious with the mean of 19.50. Conclusion. There is a Restrain Effect on Decreasing Panss EC Scores in Schizophrenic Patients with Violent Behavior with $p$ value = $0,000(\alpha<0,05)$
\end{abstract}

Keywords: restrain, schizophrenia, EC panss score, violent behavior

\section{PENDAHULUAN}

Skizofrenia merupakan suatu penyakit otak persisten dan serius yang mengakibatkan psikotik, pemikiran konkret dan kesulitan dalam memperoleh informasi, hubungan interpersonal serta memecahkan masalah (Stuart, 2010:64). Skizofrenia ditandai dengan penyimpangan yang mendasar serta karakteristik pikirsan, persepsi, serta afek yang tidak wajar dan tumpul, 
kesadaran jernih dan kemampuan intelektual biasanya tetap terpelihara walaupun kemunduran kognitif tertentu dapat berkembang kemudian (Maramis, 2010:56).

Menurut data dari Riset Kesehatan Dasar (Riskesdas, 2013, h.13) di Indonesia prevalensi gangguan mental emosional yang ditunjukan dengan gejala-gejala depresi dan kecemasan adalah sebesar 6\% untuk usia 15 tahun ke atas atau sekitar14 juta orang. Sedangkan prevalensi gangguan jiwa berat, seperti schizofrenia adalah 1,7 per 1000 penduduk atau sekitar 400.000 orang. Berdasarkan data dari dinas kesehatan propinsi Jawa Tengah tercatat ada 1.091 kasus yang mengalami gangguan jiwa dan beberapa dari kasus tersebut hidup dalam pasungan. Angka tersebut diperoleh dari pendataan sejak Januari hingga November 2012 (Hartanto, 2014). Sizofrenia biasanya timbul pada usia 18 smapai 45 tahun namun ada juga yang baru berusia 11 sampai 12 tahun sudah menderita skizofrenia (Arif, 2006 dalam Saktiyono, 2011:2).

Skizofrenia jika dibiarkan akan menyebabkan perilaku kekerasan. Hal ini terjadi karena adanya perubahan isi pikir yaitu halusinasi, baik pendegaran, penglihatan maupun penciuman (Santoso, 2010:3). Perilaku kekerasan merupakan salah stau kasus kegawatdaruratan psikiatri, sehingga perlu penanganan yang cepat dan tepat agar tidak terjadi pencideraan pada klien, orang lain maupun pengerusakan barangbarang (Santoso, 2010 : 34). Tindakan pertama yang harus dilakukan ketika pertama kali melihat keadaan gaduh, gelisah, serta perilaku kekerasan yang disebabkan oleh apapun yaitu menguasai keadaan lingkungan terutama keadaan pasien yang biasanya menggunakan ikatan pada anggota tubuh yang aktif atau sering disebut restrain/fiksasi (Endradhita, 2008:24).

Elita (2011) memperoleh hasil bahwa perilaku kekerasan yang terbanyak dilakukan klien dalam satu tahun di RSJ Tampan adalah 84\% kekerasan fisik pada diri sendiri yang menyebabkan cedera ringan, $79 \%$ kemudian diikuti oleh ancaman fisik, $77 \%$ penghinaan dan $70 \%$ kekerasan verbal dan diungkapkan bahwa $20 \%$ perawat mengalami kekerasan fisik yang menyebabkan cedera serius. Dampak perawat dalam memberikan asuhan keperawatan klien dengan perilaku kekerasan masih melakukan intervensi dengan menggunakan metode intervensi yang alami seperti pengikatan, dan belum melakukannya berdasarkan standar dan strategi dalam memberikan asuhan keperawatan klien dengan perilaku kekerasan (Darsana, 2010)

Penatalaksanaan atau penanganan perilaku kekerasan sangat diperlukan dan dapat dilakukan dengan berbagai cara, salah satunya dengan isolasi dan atau restrein (menurut kebijakan institusi). Restrain adalah aplikasi langsung kekuatan fisik pada individu, tanpa ijin individu tersebut, untuk membatasi kebebasan gerak. Restrain adalah metode manual atau peralatan mekanik, bahan atau peralatan yang bersentuhan atau berdekatan dengan tubuh klien sehingga klien tidak dapat berpindah dengan mudah dan membatasi kebebasannya untuk bergerak atau menyentuh tubuh seseorang (Potter dan Perry, 2010:56).

Terapi restrain melibatkan penggunaan alat mekanis atau manual untuk membatasi mobilitas fisik pasien. Terapi restrain dapat diindikasikan untuk melindungi pasien atau orang lain dari cidera, khususnya bila interensi perubahan lingkungan dan strategi perilaku telah gagal (Stuart dan Sundeen, 2010:34). Positive and Negative Syndrome Scale (PANSS) merupakan suatu alat ukur yang valid untuk menilai beratnya simtom yang dialami pasien skizofrenik dan penilaian terhadap keluaran terapeutik PANSS.

Berdasarkan hasil penelitian Restrain termasuk termasuk strategi pengekangan atau pengikatan. Walaupun secara etik restrain masih menjadi perdebatan, namun restrain masih menjadi tindakan yang efektif menurunkan perilaku kekerasan pada pasien skhizofrenia di Rumah Sakit Jiwa (RSJ) (Marlindawani, 2009:19). Penggunaan PANSS-EC di Rawat Jalan dan Instalasi Gawat Darurat membantu menentukan kriteria pasien indikasi rawat inap, yakni pasien dengan skor PANSS-EC sebesar > 25. Penggunaan PANSS-EC oleh para Dokter Penanggung Jawab Pasien (DPJP) pada pasien rawat jiwa membantu menilai status pasien secara berkala, sehingga dapat melakukan pemindahan pasien ke Rawat Inap sesegera mungkin ketika pasien sudah menunjukkan perbaikan gejala-gejala agitasi akut dengan skor PANSS-EC5-17 (Wahyuningsih, 2013). 
Sodikin (2015) mengatakan bahwa pemberian restrain dan standar asuhan keperawatan perilaku kekerasan memberikan hasil penurunan skor respon perilaku yang bermakna daripada hanya diberikan standar asuhan keperawatan perilaku kekerasan, sehingga perlu adanya peningkatan kualitas sumber daya perawat dalam pelaksanaan latihan asertif. Lindenmayer (2009) mengatakan bahwa penanganan pasien dengan perilaku kekerasan saat ini lebih mengedepankan terapi perilaku dan terapi non farmakologi.

Saktiyono (2011), mengatakan bahwa terdapat penurunan perilaku kekerasan pada pasien skizofrenia yang dilakukan terapi restrain, hal ini disebabkan terapi restrain dapat mempermudah pemberian psikofarma sebagai terapi utamanya. Restrain efektif menurunkan perilaku kekerasan jika diikuti pemberian psikofarma. Hal serupa diungkapkan oleh Santoso (2007) bahwa ada hubungan yang bersinergi antara restrain dan psikofarmaka dalam menurunkan tingkat perilaku kekekarasan.

Data yang diperoleh dari studi pendahuluan pada bulan Februari 2017 di bagian Rekam Medis RSJD Dr. RM. Soedjarwadi Klaten Jawa Tengah, tercatat bahwa pada bulan September sampai dengan Desember 2016 jumlah pasien skizofrenia adalah 393 pasien dengan perilaku kekerasan sebanyak 158 pasien $(40,2 \%)$. Hasil observasi yang dilakukan di ruang Edelweis dari 158 pasien yang dilakukan restrain sebanyak 72 pasien $(45,6 \%)$ hal ini menunjukkan bahwa hampir setengah dari pasien perilaku kekerasan dilakukan restrain. Ruang edelweis merupakan ruang intensif jiwa dengan kapasitas 20 tempat tidur yang terdiri dari 10 putra dan 10 putri.

Penelitiann ini bertujuan untuk mengetahui pengaruh Restrain terhadap Penurunan Skor Panss ec pada Pasien Skizofrenia dengan Perilaku Kekerasan di Ruang Edelweis Rumah Sakit Jiwa Daerah Dr. Soedjarwadi Provinsi Jawa Tengah melalui penelitian kuantitatif.

\section{METODE}

Desain penelitian ini menggunakan Quasy Eksperimental dengan rancangan One Group Pre Test-Post Test Design, yaitu melakukan test untuk mengetahui penurunan skor panss ec sebelum dan setelah dilakukan restrain dimana pada penelitian ini tidak ada kelompok kontrol atau pembanding tetapi sudah dilakukan observasi pertama (pre test) yang memungkinkan peneliti dapat menguji perubahan-perubahan yang terjadi setelah adanya eksperiment (Nursalam, 2013). Sampel pada penelitian ini adalah semua pasien perilaku kekerasan di RSJD dr. RM. Soedjarwadi Provinsi Jawa Tengah sebanyak 158 orang. Tehnik sampling yang digunakan dalam penelitian ini adalah consecutive sampling.

Adapun kriteria inklusi dan eksklusi dalam penentuan sampel penelitian yaitu: Kriteria Inklusi meliputi: Pasien skizofrenia dengan gejala perilaku kekerasan yang muncul maksimal dua hari pertama keperawatan Pasien skizofrenia dengan usia lebih dari 26-45 tahun (WHO, 2015), Pasien menderita skizofrenia lebih dari 2 tahun, Kriteria Eksklusi: Pasien perilaku kekerasan yang bukan disebabkan skizofrenia. Penelitian ini dilakukan di RSJD DR. RM. Soedjarwadi Provinsi Jawa Tengah pada tanggal 1 sampai dengan $15 \mathrm{Juli}$ tahun 2017. Uji normalitas data menggunakan uji Shapiro wilk karena jumlah sampel $\leq 50$. Uji hipotesis penelitian ini menggunakan uji t-test karena data berdistribusi normal. Tingkat kesalahan yang diambil dalam penelitian ini sebesar 5\% $(\alpha=0,05)$, perbedaan dianggap bermakna jika $\mathrm{p} \leq 0,05$.

\section{HASIL}

\section{Karakteristik Responden}

Karakteristik responden meliputi umur, jenis kelamin, pendidikan dan lama menderita.

\section{a. Umur}

Berdasarkan tabel 1 diketahui bahwa rerata umur pasien skizofrenia yaitu 33,75 tahun, dengan umur termuda 26 tahun dan tertua 45 tahun dan standar deviasi 8,07 tahun.

b. Jenis Kelamin

Berdasarkan tabel 2 diketahui bahwa sebagian besar jenis kelamin adalah laki-laki sebanyak 14 responden (70\%).

c. Pekerjaan

Berdasarkan tabel 3 diketahui bahwa sebagian besar responden tidak bekerja sebanyak 12 responden $(60 \%)$.

d. Lama Menderita

Berdasarkan tabel 4 diketahui bahwa rerata lama menderita pasien skizofrenia adalah 6,1 tahun. 
Tabel 1.

Rerata Umur Pasien Skizofrenia $(n=20)$

\begin{tabular}{lllll}
\hline & Mean & Min & Maks & SD \\
\hline Umur & 33,75 & 26 & 45 & 8,07 \\
\hline
\end{tabular}

Tabel 2.

Karakteristik responden $(\mathrm{n}=20)$

\begin{tabular}{lcc}
\multicolumn{1}{c}{ Karakteristik responden } & $\mathrm{f}$ & $\%$ \\
\hline Jenis kelamin & 6 & 30 \\
Perempuan & 14 & 70 \\
Laki-laki & & \\
Pekerjaan & 12 & 60 \\
Tidak Bekerja & 7 & 35 \\
Buruh & 1 & 5 \\
Swasta & & \\
\hline
\end{tabular}

Tabel 3.

Rerata Lama Menderita $(\mathrm{n}=20)$

\begin{tabular}{lllll}
\hline & Mean & Min & Maks & SD \\
\hline Lama Sakit & 6,1 & 2 & 10 & 5,5 \\
\hline
\end{tabular}

\section{Hasil Uji Kappa}

Hasil uji kappa pada 1 asisten didapatkan nilai dengan $\mathrm{p}=0,006(\mathrm{p}<0,05)$ jadi asisten valid koeefisien Kappa 0,828 lebih dari 0,7 dan untuk mengikuti penelitian.

Tabel 4.

Rerata Skor Panns EC Sebelum dan Sesudah Restrain $(n=20)$

\begin{tabular}{lllll}
\hline Kelompok & Mean & Min & Maks & SD \\
\hline Sebelum & 21,90 & 20,00 & 25,00 & 1,58 \\
Sesudah & 19,50 & 15,00 & 24,00 & 1,96 \\
\hline
\end{tabular}

Berdasarkan tabel 5 diketahui bahwa rerata skor Panns EC sebelum dilakukan restrain adalah 21,90 dan setelah dilakukan restrain rerata skor Panns EC adalah 19,50. Hal ini berarti terjadi penurunan skor panss EC.

\section{Uji Normalitas Data}

Uji normalitas dilakukan menggunakan Saphiro Wilk, karena jumlah sampel kurang dari 50.

Tabel 5 .

Uji Normalitas

\begin{tabular}{|c|c|c|c|}
\hline Data & $\mathrm{p}$ & A & Keterangan \\
\hline Pre & 0,159 & 0,05 & Normal \\
\hline Post & 0,067 & 0,05 & Normal \\
\hline
\end{tabular}

Keterangan : Uji Shapiro Wilks

Berdasarkan table 4.6 diketahui bahwa pre dengan nilai $\rho=0,159(\alpha>0,05)$ dan post $\rho=$ Pengaruh Restrain terhadap Penurunan Skor Panss EC pada Pasien Skizofrenia dengan Perilaku Kekerasan

$0,067(\alpha>0,05)$ maka data berdistribusi normal.

Pengaruh Restrain terhadap Penurunan Skor Panss EC pada Pasien Skizofrenia dengan Perilaku Kekerasan dapat dilihat pada tabel 6 berikut ini.

Tabel 6.

Pengaruh restrain terhadap penurunan skor panss ec $(n=20)$

\begin{tabular}{|c|c|c|c|c|c|c|}
\hline \multirow{2}{*}{ Kelompok } & \multirow[t]{2}{*}{$\mathrm{t}$} & \multirow[t]{2}{*}{ df } & \multirow[t]{2}{*}{ Mean } & \multicolumn{2}{|c|}{ CI 95\% } & \multirow{2}{*}{$\mathrm{p}$} \\
\hline & & & & Lower & Upper & \\
\hline $\begin{array}{l}\text { Sebelum } \\
\text { Sesudah }\end{array}$ & 4,222 & 19 & 2,40 & 1,21 & 3,58 & 0,00 \\
\hline
\end{tabular}


Berdasarkan hasil uji statistic dengan paired $t$ test didapatkan nilai $\rho=0,000(\alpha<0,05)$ dan nilai $\mathrm{t}=4,222$ dengan nilai mean 2,40 , maka $\mathrm{Ha}$ diterima dan Ho ditolak jadi ada pengaruh Restrain terhadap Penurunan Skor Panss EC pada Pasien Skizofrenia dengan Perilaku Kekerasan di Ruang Edelweis Rumah Sakit Jiwa Daerah Dr. Soedjarwadi Provinsi Jawa Tengah

\section{PEMBAHASAN}

\section{Karakteristik Responden}

1. Umur

Distribusi responden menurut umur menunjukkan bahwa rerata umur pasien skizofrenia yaitu 36,40 tahun, umur termuda 26 tahun dan umur tertua 45 tahun jadi umur responden dalam penelitian ini 26-45 tahun. Berdasarkan hasil penelitian dapat diasumsikan usia responden termasuk usia produktif sehingga pada umumnya pada usia tersebut seseorang ingin beraktualisasi secara maksimal, sehingga segala sesuatu bila tidak terwujud akan timbul kekecewaan dan bila mekanisme koping tidak efektif potensial terjadinya gangguan jiwa, salah satunya perilaku kekerasan. Hasil ini sesuai pendapat Keliat (2010), bahwa sebagian besar pasien gangguan jiwa yang datang pertama kali menunjukkan perilaku kekerasan.

Hasil ini sesuai dengan penelitian Elita (2011) bahwa umur terbanyak pada pasien perilaku kekerasan adalah 45 tahun. Hasil ini didukung juga dengan penelitian Kandar (2014), rentang umur pasien dengan perilaku kekerasan adalah 25-45 tahun. Karakteristik yang termasuk pada sosial budaya seperti usia, jenis kelamin, pendidikan, pekerjaan,peran sosial, latar belakang budaya, agama, dan keyakinan individu (Stuart \& Laraia, 2010), serta riwayat perilaku kekerasan dimasa lalu, semua adalah faktor-faktor yang dapat menyebabkan terjadinya perilaku kekerasan pada individu (American Psychiatric Assosiations, 2000, dalam Dewi Eka, 2010).

\section{Jenis Kelamin}

Responden dalam penelitian ini sebagian besar jenis kelamin pasien adalah laki-laki sebanyak 14 responden (70\%). Hasil ini sesuai dengan penelitian Kandar (2014) bahwa mayoritas responden yang mengalami perilaku kekerasan adalah dengan jenis kelamin laki-laki, cenderung memiliki beban berat. Kehidupan sosial budaya seorang individu seperti, usia, jenis kelamin, pendidikan, pekerjaan, peran sosial, latar belakang budaya, agama, dan keyakinan individu (Stuart \& Laraia, 2010) akan mempengaruhi seseorang dalam berperilaku. Pada umumnya laki-laki mempunyai sebuah tanggung jawab yang lebih besar dibandingkan perempuan sehingga tuntutan tanggung jawab dalam kehidupan juga akan semakin tinggi. Secara fisik struktur otot pada laki-laki lebih kuat, hal ini menjadi peluang mudah untuk melakukan perilaku kekerasan. Penelitian ini menunjukan bahwa jenis kelamin mempengaruhi akan kejadian perilaku kekerasan pada individu.

Hasil penelitian ini juga didukung oleh Fontaine dan Fletcher (2010, h.3) yang menyatakan bahwa kemampuan keluarga ditentukan oleh kemampuan untuk mamajemen stress yang produktif. Kelelahan fisik dan emosi selama merawat anggota keluarga dengan gangguan jiwa sering melanda keluarga karena berkurangnya stress tolerance.

\section{Pekerjaan}

Pekerjaan responden, sebagian besar tidak bekerja sebanyak 60\%. Menurut Keliat 2003 salah satu penyebab stress adalah karena status pekerjaan yang tidak tetap. Kondisi sosial lain yang dapat juga menimbulkan perilaku kekerasan seperti halnya, keluarga single parent, pengangguran, kesulitan mempertahankan tali persaudaraan, struktur keluarga, dan kontrol sosial (Stuart \& Laraia, 2015). Penelitian ini menunjukan bahwa seseorang jika tidak bekerja/menganggur akan menimbulkan aktivitas yang tidak bermakna atau tidak bermanfaat sehingga dapat mempengaruhi timbulnya perilaku kekerasan pada individu.

Penelitian yang dilakukan Keliat (2010), menyebutkan karakteristik pendidikan, status perkawinan, dan pekerjaan mempengaruhi dalam kejadian perilaku kekerasan. Hal ini lebih lanjut diutarakan oleh Stuart \& Laraia (2010) dimana kondisi sosial seperti pengangguran menjadi salah satu faktor sosial yang dapat menimbulkan perilaku kekerasan. Hidayat (2010) juga mengatakan bahwa tidak adanya pekerjaan merupakan salah satu faktor yang berpengaruh dalam kesehatan jiwa seseorang. Sehingga pekerjaan memang bisa menjadi stressor dan berkontribusi dalam menyebabkan perilaku kekerasan. 


\section{Lama Menderita}

Hasil penelitian menunjukkan mayoritas menderita gangguan jiwa lebih dari 2 tahun atau bisa dikatakan cukup lama. Stuart dan Laraia (2010) yang menyatakan bahwa waktu atau lamanya terpapar stressor, yakni terkai sejak kapan, sudah berapa lama dan berapa kali kejadian (frekwensi), akan memberikan dampak adanya keterlambatan dalam mencapai kemampuan dan kemandirian. Keliat (2010) yang menyatakan semakin singkat klien sakit dan terpapar dengan lingkungan pelayanan rumah sakit akan memberikan keuntungan kepada klien dan keluarga, hal ini akan meminimalkan kemunduran fungsi sosial. Klien lebih mudah diarahkan dalam pemberian intervensi sehingga peningkatan kemampuan klien lebih cepat. Menurut peneliti meskipun mayoritas klien menderita gangguan jiwa dalam waktu yang cukup lama tetapi sebian besar dirawat oleh anggota keluarga dirumah.

Hasil ini sesuai dengan Eliana (2011) bahwa lama menderita gangguan jiwa 2-4 tahun sebanyak $40 \%$, dan riwayat dirawat 3-4 kali sebanyak $40 \%$. Lama seseorang mengalami gangguan jiwa dan berapa kali dirawat merupakan factor pendukung atau predisposisi seseorang untuk kambuh kembali.

\section{Skor Panss EC}

Hasil penelitian skor pans ec pada pasien skizofrenia sebelum diberikan restrain sebagian besar adalah lebih dari 20 atau dalam kategori gaduh gelisah. Hal ini menunjukkan bahwa pasien mengalami gaduh dan gelisah. Pasien dinyatakan gelisah karena percepatan perilaku motorik terhadap stimuli, waspada berlebihan dan labilitas alam perasaan yang berlebihan. Gaduh gelisah (P4) merupakan hiperaktivitas yang ditampilkan dalam bentuk percepatan perilaku motorik, peningkatan respon terhadap stimuli, waspada berlebihan atau labilitas perasaan yang berlebihan. Hasil dari penelitian menunjukkan bahwa skor komposit gejala perilaku kekerasan (penjumlahan respon perilaku, sosial, kognitif, fisik dan PANSS-EC) sebelum pemberian restrain mengalami gelisah, setelah diberikan retrain terjadi penurunan. Tindakan pertama yang harus dilakukan ketika pertama kali melihat keadaan gaduh, gelisah, serta perilaku kekerasan yang disebabkan oleh apapun yaitu menguasai keadaan lingkungan terutama keadaan pasien yang biasanya menggunakan ikatan pada anggota tubuh yang aktif atau sering disebut restrain/fiksasi (Endradhita, 2008:24).

Penurunan bermakna respon perilaku terjadi padakedua kelompok. Namun, secara substansi penurunan skor perilaku lebih besar terjadi pada kelompok intervensi yang mendapatkan restrain (skor tinggi ke rendah) dari pada kelompok yang tidak mendapatkan restrain (skor tinggi ke sedang). Hal ini sesuai dengan penelitian yang dilakukan oleh Keliat (2010), bahwa pemberian terapi restrain pada pasien perilaku kekerasan menghasilkan kemampuan mencegah perilaku kekerasan secara mandiri sebesar 86,6\% dan secara signifikan menurunkan perilaku kekerasan.

Pemberian terapi restrain perilaku kekerasan ini melatih kemampuan klien secara kognitif berupa pemahaman tentang perilaku kekerasan, afektif berupa kemauan untuk mengontrol perilaku kekerasan yang dilatih dan psikomotor berupa cara mengontrol perilaku kekerasan yang konstruktif.

Hasil penelitian diatas sejalan dengan penelitian yang dilakukan oleh Hayakawa (2009) yang menyatakan bahwa latihan asertif yang deberikan pada pasien dengan gangguan kepribadian dapat menurunkan perilaku agresif yang diarahkan pada diri sendiri, hal senada juga disampaikan oleh Rezan (2009), Lee (2013) bahwa pemberian restrain dapat menurunkan tingkat agresifitas yang diarahkan pada diri sendiri maupun pada lingkungan.

\section{Pengaruh Restrain terhadap Penurunan Skor Panss EC pada Pasien Skizofrenia dengan Perilaku Kekerasan}

Berdasarkan hasil uji statistic dengan paired ttest didapatkan nilai $\rho=0,000(\alpha<0,05)$ dan nilai $\mathrm{t}=4,222$ dengan nilai mean 2,40, maka $\mathrm{Ha}$ diterima dan Ho ditolak jadi ada pengaruh Restrain terhadap Penurunan Skor Panss EC pada Pasien Skizofrenia dengan Perilaku Kekerasan di Ruang Edelweis Rumah Sakit Jiwa Daerah Dr. Soedjarwadi Provinsi Jawa Tengah. Hasil ini sesuai dengan penelitian Sulistyowati (2013) bahwa Penggunaan Restrain efektif Terhadap Penurunan Perilaku Kekerasan Pada Pasien Skizofrenia. Didukung juga dengan penelitian Kandar (2014) bahwa Pelaksanaan prosedur tindakan restrain pada pasien perilaku kekerasan yang menjalani Perawatan di Unit 
Perawatan Intensif Psikiatrik (UPIP) RSJD Dr. Amino Gondohutomo Semarang.

Perilaku kekerasan merupakan salah satu respon marah yang diekspresikan dengan melakukan ancaman, mencederai orang lain, dan atau merusak lingkungan yang bertujuan untuk melukai seseorang secara fisik maupun psikologis (Keliat et al. 2011). Semakin tinggi skor perilaku kekerasan menunjukkan bahwa gejala perilaku kekerasan semakin berat hal ini berdampak juga terhadap memanjangnya lama hari rawat dan angka kekambuhan (relaps) pasien (Zhang, 2011). Saktiyono (2011), mengatakan bahwa terdapat penurunan perilaku kekerasan pada pasien skizofrenia yang dilakukan terapi restrain, hal ini disebabkan terapi restrain dapat mempermudah pemberian psikofarma sebagai terapi utamanya. Restrain efektif menurunkan perilaku kekerasan jika diikuti pemberian psikofarma. Hal serupa diungkapkan oleh Santoso (2007) bahwa ada hubungan yang bersinergi antara restrain dan psikofarmaka dalam menurunkan tingkat perilaku kekekarasan. Keluarga membawa klien ke rumah sakit karena melakukan perilaku kekerasan seperti mengamuk, melukai orang lain, merusak lingkungan dan marah-marah. Penelitian yang dilakukan oleh Keliat (2010) menyebutkan bahwa perilaku kekerasan merupakan salah satu gejala yang menjadi alasan bagi keluarga untuk merawat klien di rumah sakit jiwa karena beresiko membahayakan bagi diri sendiri dan orang lain.

Pemberian terapi restrain lebih efektif untuk menurunkan respon perilaku dari pada hanya dengan terapi generalis. Hasil penelitian yang dilakukan Bregman (1984, dalam Forkas (2012) menyatakan bahwa terapi restrain berpengaruh positif terhadap kemampuan berkomunikasi secara asertif dengan melibatkan aspek nonverbal. Metode pelaksanaan restrain akan memotivasi klien untuk lebih berperan aktif berfikir dan berlatih terhadap kemampuan sosial atau verbal yang diajarkan. Penurunan bermakna skor respon kognitif klien skizoprenia setelah restrain dari skor tinggi ke rendah, menunjukkan adanya pengaruh restrain terhadap respon kognitif. Keliat dan Sinaga (2011), menyatakan bahwa latihan asertif akan melatih individu menerima diri sebagai orang yang mengalami marah dan membantu mengeksplorasi diri dalam menemukan alasan marah.
Keefektifan restrain terhadap penurunan perilaku kekerasan. Respon perilaku kekerasan yang dilakukan observasi meliputi respon perilaku, fisik, emosi dan verbal. Penggunaan restrain efektif terhadap penurunan perilaku kekerasan pada pasien Skizofrenia. Penurunan ini meliputi penurunan pada respon fisik, dikarenakan dengan adanya pembatasan gerak sehingga dapat mengurangi agresif fisik klien ( Videbecck, 2008). Respon fisik akan mempengaruhi respon emosi (Boyd Nihart, 2010). Respon fisik merupakan respon yang mengikuti perubahan kognitif pada klien perilaku kekerasan (Boyd \& Nihart, 2010).

Penilaian seseorang terhadap stressor memberikan makna dan dampak dari suartu situasi yang menekan dan ditunjukkan dengan respon kognitif, afektif, respon fisik, respon perilaku dan social (Stuart \& laraia, 2010). Dengan pemberian restrain yang sistematis klien akan melakukan kontrol terhadap emosi yang mempengaruhi proses fikir serta ketegangan otot (Stuart\& Laraia, 2010) Dengan demikian restrain efektif menurunkan perilaku kekerasan pada pasien Skizofrenia (Videbecck, 2008).

Menurut Suryani dalam Hendriyana (2013), stigma terhadap penderita gangguan jiwa di Indonesia masih sangat kuat. Dengan adanya stigma ini, orang yang mengalami gangguan jiwa terkucilkan, dan dapat memperparah gangguan jiwa yang diderita. Pada umumnya penderita gangguan jiwa berat dirawat dan diberi pengobatan di rumah sakit. Setelah membaik dan dipulangkan dari rumah sakit, tidak ada penanganan khusus yang berkelanjutan bagi penderita. Pengobatan penderita gangguan jiwa merupakan sebuah journey of challenge atau perjalanan yang penuh tantangan yang harus berkelanjutan. Penderita gangguan jiwa sulit untuk langsung sembuh dalam satu kali perawatan, namun membutuhkan proses yang panjang dalam penyembuhan. Karena itu, dibutuhkan pendampingan yang terus menerus sampai pasien benar-benar sembuh dan bisa bersosialisasi dengan orang lain secara normal. Ketika di rumah, dukungan dari keluarga dan lingkungan sekitar sangat dibutuhkan agar penderita bisa menjalani proses penyembuhannya.

Ketiadaan akses terkait keberlanjutan dari proses penyembuhan dan pengobatan rutin membuat 
keluarga yang memiliki anggota keluarga dengan gangguan jiwa berat melakukan pemasungan. Dikarenakan sebagian besar keluarga dan penderita tinggal di wilayah perdesaan. Awal gejala gangguan jiwa yang tidak terdeteksi menyebabkan keterlambatan penanganan penderita gangguan jiwa. Keterlambatan penanganan juga disebabkan oleh stigma terhadap penderita gangguan jiwa, sehingga keluarga akan menolak apabila ada anggota keluarga yang dideteksi memiliki gejala gangguan jiwa. Sehingga penderita gangguan jiwa akan cepat bertambah parah yang apabila sudah dianggap mengganggu serta membahayakan diri dan lingkungan sekitarnya maka akan dengan sangat terpaksa dilakukan pemasungan. Mekanisme copingyang dilakukan oleh keluarga terkait dengan sebab-sebab terganggunya jiwa anggota keluarganya, sebagian besar disangkutpautkan dengan kejadian-kejadian mistik atau supranatural yang dialami oleh penderita atau keluarganya. Selain itu, penolakan atas labelling gangguan jiwa juga dilakukan oleh penderita sendiri menyebabkan penolakan atas pengobatan yang dijalaninya. Wardhani, dkk. (2011) pasien C penderita gangguan jiwa berat yang dipasung kedua kakinya pada kayu besar menyatakan bahwa dia sehat tidak merasa sakit.

\section{SIMPULAN}

Karakteristik responden meliputi rerata umur responden 33,75 tahun dan umur termuda 26 tahun serta umur tertua 45 tahun, jenis kelamin mayoritas laki-laki, pekerjaan adalah tidak bekerja dan rerata lama menderita 6,1 tahun. Skor Panss EC pada pasien skizofrenia sebelum dilakukan restrain yaitu gaduh gelisah dengan mean 21,90 termasuk dalam gaduh gelisah. Skor Panss EC pada pasien skizofrenia setelah dilakukan restrain yaitu gelisah dengan mean 19,50 termasuk dalam gelisah. Ada Pengaruh Restrain terhadap Penurunan Skor Panss EC pada Pasien Skizofrenia dengan Perilaku Kekerasan di Ruang Edelweis Rumah Sakit Jiwa Daerah Dr. Soedjarwadi Provinsi Jawa Tengah dengan nilai $p=0,000(\alpha<0,05)$

\section{DAFTAR PUSTAKA}

Arikunto, S. (2010). Prosedur Suatu Pengantar Kesehatan. Jakarta : Rineka Cipta
Ambarwati, Wahyu Nur. (2009). Keefektifan CBT sebagai Terapi Tambahan Pasien Skizofrenia Kronis di Panti Rehabilitasi Budi Makarti Boyolali.Tesis. Surakarta: Fakultas Kedokteran Universitas Sebelas Maret

Depkes RI. (2007). Standar Pelayanan Kebidanan. Jakarta.

Dewi Eka. (2010). Gambaran Pengaruh REB Therapi terhadap penurunan Perilaku kekerasan di RSJ Bogor. Skripsi. Bogor

Eliana. (2011). Hubungan Antara Prasangka Dengan Perilaku Agresif Pada Masyarakat Jawa Terhadap Masyarakat Tionghoa Di Kelurahan Kemlayan Surakarta. Skripsi. UNS: Surakarta.

Elita, (2012). Persepsi Perawat tentang Perilaku Kekerasan di Ruang Rawat Jiwa. Jurnal Ners Indonesia, Vol.1, No. 2, Marel 2011

Endradhita. (2008). Gambaran Perilaku Kekerasan di RSJD dr. Soepramo. Skripsi. UNS

Farida dan Hartono, Yudi, (2010), Buku Ajar Keperawatan Jiwa, Jakarta : Salemba Medika

Fletcher, A. C., et.al. (2010). Parenting style as a moderator of associations between maternal disciplinary strategies and child wellbeing. Journal of Family Issues, 29, 1724-174

Foster, Bowers, Nijman. (2007). Aggressive behaviour on acute psychiatric wards: prevalence, severity and management. Journal of Advanced Nursing,58,140-149

Hayakawa, M. (2009). How Repeated 15Minute Assertiveness training Sessions Reduce Wrist Cutting In Patients With Borderline Personality Disorder. American Journal of Psychotherapy, 63(1).

Hidayat, Aziz Alimul,A. (2008). Pengantar Konsep Dasar Keperawatan.Edisi ke 2.Jakarta : Salemba Medika. 
Hurlock. (2010). Psikologi Perkembangan. Jakarta: EGC

Kandar. (2014). Efektivitas Tindakan Restrain Pada Pasien Perilaku Kekerasan Yang Menjalani Perawatan Di Unit Pelayanan Intensif Psikiatri (UPIP) RSJ Daerah Dr. Amino Gondohutomo Semarang. Prosiding PPNI II tahun 2014. www.ppnijateng.or.id/page111

Kandar (2014) tentang Pelaksanaan prosedur tindakan restrain pada pasien perilaku kekerasan yang menjalani Perawatan di Unit Perawatan Intensif Psikiatrik (UPIP) RSJD Dr. Amino Gondohutomo Semarang

Lee, T.Y., Chang S.C., Chu H., Yang C.Y., Ou K.L., Chung M.H., Chou K.R., (2013). The effect of assertiveness training in patients with schizophrenia : a randomized, single - blind, controlled study. Journal of Advanced Nursing, 69 (11):2549 -255

Lindenmayer.J.P, Kanellopoulou.I. (2009). Schizophrenia with Impulsive and Aggressive Behaviors.PsychiatrClin $N$ Am32 : 885902doi:10.1016/j.psc.2009.08.006

Maramis, W.F. (2012). Catatan Ilmu Kedokteran Jiwa. Surabaya : Airlangga University Press.

Nasir, A \& Muhith, A. (2011). Dasar Dasar Keperawatan Jiwa. Jakarta : Salemba Medika

Potter dan Perry. (2010). Buku ajar fundamental keperawatan volume 2. Edisi 4, Jakarta : EGC

Putri, Dewi Eka (2010). Pengaruh rational emotive behaviour therapy terhadap klien perilaku kekerasan di ruang rawat inap RSMM Bogor tahun 2010.Fakultas Keperawatan.Depok.

Rezan, A \& Zengel, M. (2009).Elementary Education Online, 8(2), 485-492 http://ilkogretim-online.org.tr.
Riskesdas. (2013). Badan Penelitian dan Pengembangan Kesehatan Departemen Kesehatan Republik Indonesia 2008.http://digilib.esaunggul.ac.id/public/ UEU-Undergraduate-211-

1.pdfDiunduhpada tanggal 4 januari 2014 jam 07.30 WIB

Santoso, A. (2010). Statistik Untuk Psikologi. Yogyakarta: Universitas Sanata Dharma.

Sinaga. BR. (2007). Skizofrenia dan diagnosis banding. Jakarta. Balai penerbit FKUI

Stuart dan Sundeen, (2010). Buku Saku Keperawatan,Edisi 3. Jakarta : EGC

Stuart,G.W. and Laraia, M.T. (2010). Prinsip dan Praktik Keperawatan Psikiatrik. Jakarta: EGC

Sulistyowati (2013) tentang Efektiftas Penggunaan Restrain Terhadap Penurunan Perilaku Kekerasan Pada Pasien Skizofrenia

Townsend, M. C, (2009), Psychiatric Mental Healt Nursing : Concepts of Care inEvidence-BasedPractice(6thed.), Philadelphia : F.A. Davis

Triantoro. (2009). Manajemen Emosi, Bumi Aksara, Jakarta

Videbeck, S. L. (2008).Buku Ajar Keperawatan Jiwa.Jakarta: Buku Kedokteran EGC

Wahyuningsih, D. (2009). Pengaruh Assertiveness training (AT) Terhadap Perilaku Kekerasan Pada Klien Skizophrenia Di RSUD Banyumas.Universitas Indonesia, Tesis FK-UI. Tidak Dipublikasikan

Yosep, I. (2013). Keperawatan Jiwa. Bandung : PT Refika Aditama

Zhang.J, Harvey.C , Andrew. C., (2011). Factors associated with length of stay and the risk of readmission in an acute psychiatric inpatient facility: a retrospective study. Australian and New Zealand Journal of Psychiatry, 45, . 
Jurnal Keperawatan Jiwa Volume 7 No 2 Hal 135 - 144, Agustus 2019

FIKKes Universitas Muhammadiyah Semarang bekerjasama dengan PPNI Jawa Tengah 